\title{
Structure and Temperature Regulated Expression of a Cysteine Proteinase Gene in Pachysandra terminalis Sieb. \& Zucc.
}

\author{
Suping Zhou ${ }^{1}$, Roger Sauve, and Fur-Chi Chen \\ Tennessee State University, Institute of Agricultural and Environmental Research, 3500 \\ John A. Merritt Blvd., Nashville, TN 37209
}

\begin{abstract}
AdDitional INDEX words. cold, heat, dark, pro region motif, papain-like proteinase, real-time-qRT-PCR
Abstract. A cysteine proteinase gene (DQ403257) with an open reading frame of 1125 base pairs was isolated from Pachysdandra terminalis. The primary translated peptide has a predicted length of 374 amino acids, pI (isoelectric point) of 5.70, and molecular mass of $40.9 \mathrm{kDa}$. The Peptidase_C1 domain is between residue 141 and 367. The proteinase has a conserved motif Gly-Xaa-Thy-Xaa-Phe-Xaa-Asn in the pro region. Sequence comparison shows that the deduced peptide shares $82 \%$ identity with the cysteine proteinase RD19a precursor (RD19) (accession P43296) from Arabidopsis thaliana (L.) Heynh. Real-time quantitative reverse-transcriptase-polymerase chain reaction revealed that the gene is induced by treatments of 1 to 7 days of darkness, 2 hours and 3 to 7 days at $5^{\circ} \mathrm{C}$, and 3 days at $38{ }^{\circ} \mathrm{C}$.
\end{abstract}

Proteinases are the catalyst in the hydrolysis reaction of peptide linkages in oligopeptides or polypeptides (van der Hoorn et al., 2004). The enzymes function to maintain strict protein quality control by degrading specific sets of proteins in response to diverse environmental and developmental stimuli. Proteinases are grouped into four major classes according to their catalytically important residues: serine proteinases (e.g., trysin), cysteine protease (papain), aspartic acid proteinase (pepsin), and metalloproteinases (thermolysin and carboxypeptidase $\mathrm{A}$ ).

Cysteine proteinases are a class of enzymes requiring the thiol group of a cysteine residue for their catalytic activity. Many cysteine proteinases from animals, plants, and microbial sources have been characterized (Rawlings and Barrett, 1994). Cysteine proteinases have emerged as key enzymes in the regulation of programmed cell death in animals and plants (Solomon et al., 1999). They are induced by environmental stresses such as drought (Guerrero et al., 1990; Harrak et al., 2001; Koizumi et al., 1993; Williams et al., 1994), salt (Koizumi et al., 1993), and temperature (Schaffer and Fischer, 1990). These enzymes are involved in developmental processes of senescence (Drake et al., 1996; Griffiths et al., 1997; Jones et al., 2005; Ueda et al., 2000), seed maturation and germination (Becker et al., 1994; Domoto et al., 1995; Jones et al., 1996; Okamoto et al., 2001; Shintani et al., 1995; Tsuji et al., 2004). Proteinases can affect activity of other enzymes by breaking some of the peptide bonds and cause changes in the quaternary or tertiary structures of targeted proteins. Peroxidase and rubisco-1, 5-bisphosphate carboxylase-oxygenase is found to be activated by proteinases (Chollet and Anderson, 1977; Grzywnowicz et al., 1992, 1993). Cystenine proteinase is

Received for publication 25 June 2006. Accepted for publication 28 Sept. 2006. This research was financially supported through the U.S. Department of Agriculture, Cooperative State Research, Education and Extension Service, project award number 2002-38814-12598. Dr. Nick Gawel and Ms. Sarabjit M Bhatti at Tennessee State University have reviewed the paper.

${ }^{1}$ Corresponding author. E-mail: zsuping@tnstate.edu involved in disease resistance by activating different disease resistance proteins (Avrova et al., 1999).

We have cloned a full-length cystenine proteinase gene from $P$. terminalis while analyzing its mechanism for cold tolerance. This article reports the structural characterization of the encoded proteinase protein. Recent evidence demonstrates that activation of gene expression constitutes one response to temperature stresses (Provart et al., 2003). Real-time quantitative reverse transcriptase (qRT-PCR) has been used to quantify the level of transcripts present in plant organs (Charrier et al., 2002; Lammers et al., 2001), thus predicting the transcription regulation of the genes. This technique was used to evaluate the regulation of low and high temperature stresses on the cloned gene.

\section{Materials and Methods}

CDNA LIBRARY CONSTRUCTION AND SCREENING. Total RNA extraction, cDNA library construction, and screening followed the same procedure as previously described (Zhou et al., 2006). Briefly, a cDNA library was constructed with mRNA extracted from cold-treated leaf tissues and packed into $\lambda \mathrm{gt} 11$ phagemid using the ZAP-cDNA Synthesis and ZAP- cDNA Gigapack III Gold Cloning Kit (Stratagene, La Jolla, Calif.). The leaf cDNA library was screened by plaque hybridization using the 230-base pair (bp) insert fragment of a PCR clone previously isolated (Zhou et al., 2005). The probes were labeled with ${ }^{32} \mathrm{P}-\mathrm{dATP}$ through random priming methods described in the Hot-Prime Kit (Genhunter, Nashville, Tenn.). Through second plague hybridization, the positive clones were isolated and phage DNA was prepared from them. The cDNA was subcloned into pBlueScript SK-phagemid vector.

Temperature treatments and REal-TIME QUantitative REVERSE TRANSCRIPTASE POLYMERASE CHAIN REACTION ASSAY. Seedlings with two mature leaves (dark green) and two fresh leaves (light green and fully expanded) were supplied by Yoder Brothers (Barberton, Ohio). On arrival, these seedlings were incubated at $25^{\circ} \mathrm{C}$ and weak light (indoor of the laboratory) for $3 \mathrm{~d}$ to recover from stresses induced during transportation 
process. Leaf tissues collected at this stage were considered controls. For temperature treatments, these plants were incubated at 25,5 , and $38^{\circ} \mathrm{C}$ in total darkness for $2 \mathrm{~h}, 4 \mathrm{~h}, 9 \mathrm{~h}, 23 \mathrm{~h}$, $2 \mathrm{~d}, 3 \mathrm{~d}, 6 \mathrm{~d}$, and $7 \mathrm{~d}$. At the end of each treatment, fresh leaves were harvested from a pool of three plants. Isolation of total RNA and removal of genomic DNA followed the same procedures as described by Zhou et al. (2006).

The oligonucleotide primers specific for the proteinase gene were 5'-GTTCAAAGCGGTTGTTGGAT-3' -forward/5' TCCCTTTTCTCCCCAACTCT-3' -reverse (amplicon size $110 \mathrm{bp}$ ). The housekeeping gene 18S ribosomal RNA (18S rRNA) was selected to normalize the result of q-PCR reactions. Its primers were designed using the GeneBank sequence (accession NC-003071). The forward/reverse primers were 5'-GGGGGCATTCGTATTTCATA-3'/5' -AACATCCT TGGCAAATGCTT -3' (amplicon size $100 \mathrm{bp}$ ). The real-time PCR reaction mixtures contained cDNA (100 pg total RNA), primer mix $(250 \mu \mathrm{M}$ each), and $2 \times$ PCR master mix supplied in the SYBR-green PCR mix/RT kit (Applied Biosystems, Foster City, Calif.). The PCR amplification was preformed using a program of 40 cycles of $94^{\circ} \mathrm{C}, 30 \mathrm{~s}$, and $60^{\circ} \mathrm{C}, 1 \mathrm{~min}$ on a 7000 Real Time PCR System (Applied Biosystems). At the end of the 40 cycles, the data were analyzed with the ABI Prism 7000 SDS software (Applied Biosystems) and reported as cycle threshold $\left(\mathrm{C}_{\mathrm{T}}\right)$ value. Primer specificity was validated by the dissociation kinetics and separation of PCR products on agarose gels.

In one experiment, three $\mathrm{C}_{\mathrm{T}}$ values, corresponding to the absolute transcript levels, were produced for each sample. The experiments were repeated three times independently, and the data were averaged. To minimize errors introduced during handling process, each real-time PCR reaction was repeated two times to produce two $\mathrm{C}_{\mathrm{T}}$ values. The results were averaged and considered as the $\mathrm{C}_{\mathrm{T}}$ value for that $\mathrm{PCR}$ reaction. Data analysis was through the relative quantification using the comparative $\mathrm{C}_{\mathrm{T}}$ method (ABI Prism 7700 Sequence Detection System, User Bulletin \#2; Applied Biosystems). Values of $\Delta \mathrm{C}_{\mathrm{T}}$ were calculated to represent the accumulation of gene transcripts. Fold changes were used to compare difference between treatment and control.

Primer design ANd SYNThesis, SEQuence anAlysis, AND DATABASE SEARCH. DNA sequence analysis was performed on a 3100 Avant Genetic Analyzer using a BigDye Terminator 3.1 Cycle Sequencing Kit (Applied Biosystems). All the PCR primers were designed using OligoPerfect Designer (Invitrogen, 2006). The primers and DNA sequence primers were purchased from Invitrogen (Carlsbad, Calif.). Protein translation was performed using ExPaSy translation tool (Swiss Institute of Bioinformatics, 2006). The conserved domains were predicted using MotifScan (Falquet et al., 2002). Signal peptide was predicted with the eukaryotic linear motif resources for functional sites in proteins (Puntervoll et al., 2003).

\section{Results}

Cloning and Characterization of the Putative Cysteine PROTEINASE IN P. TERMinalis. A 230-bp cDNA clone has been previously isolated from leaf tissues of $P$. terminals that shared high identity with C-terminal sequence of cysteine proteinases (Zhou et al., 2005). Screening of $\approx 2.0 \times 10^{5}$ independent recombinant clones from a $\lambda$ gt11 cDNA library with this fragment identified two positive clones. Comparison of the nucleotide sequences of the cDNAs revealed that these two positive clones were identical. Both have a length of $1350 \mathrm{bp}$ and an open reading frame of 1125 bp (NCBI accession DQ403257).

To characterize the primary structure of the gene, the DNA sequence was translated into protein using the ExPaSy translation tool. The deduced polypeptide has a predicted length of 374 amino acids, molecular mass of $40.9 \mathrm{kDa}$, and a $\mathrm{pI}$ of 5.70 . The polypeptide showed an identity of $82 \%$ to the cysteine proteinase RD19a precursor (RD19) in A. thaliana (P43296), $80 \%$ to the cysteine proteinase 1 precursor in Zea mays L. (Q10716D), and 75\% to the cysteine proteinase 15A precursor in Pisum sativum L. (P25804, Turgor-responsive protein 15A). Further structural analysis revealed that the primary translation product of the cloned gene (DQ403257) has three regions: a signal sequence, a pro region, and mature proteinase domain (Fig. 1), similar to most of the cysteine proteinases (Kassell and Kay, 1973; Neurath, 1984; van der Hoorn et al., 2004).

IDENTIFICATION OF THE CONSERVED MOTIF IN THE PRO REGION OF CYSTEINE PROTEINASE FROM DIFFERENT PLANT SPECIES. The signal sequence and pro regions are variable among cysteine proteinases. Vernet et al. (1995b) aligned 56 cysteine proteinases and identified a conserved amino acid motif of a stretch of seven residues located between -42 and -36 (papain numbering) in the pro region. This sequence motif is Gly-Xaa-Asn-XaaPhe-Xaa-Asp (GxNxFxD). It appeared in all noncathepsin B and $\mathrm{C}$ members of papain group and, in the case of kinetoplastids, the place of Asn is replaced by Thr and the motif becomes Gly-Xaa-Try-Xaa-Phe-Xaa-Asp (GxTxFxD). Table 1 shows the conserved motif of cysteine proteinases from different plant species. The GxTxFxD motif is conserved in P. terminalis, A. thaliana, Phaseolus vulgaris L., Ipomoea batatas (L.) Lam., Vigna mungo (L.) Hepper, Z. mays, Phaseolus vulgaris L., P. sativum, Lycopersicon esculentum Mill, Brassica napus L., and Solanum tuberosum L. Some of the plant species contain cysteine proteinases that have either the motif of GxNxFxD or GxTxFxD. In the case of $A$. thaliana, seven of the cysteine proteinases have the conserved motif as GxTxFxD (AAM96982, T13022, E85435, AAK92229, JN0719, BAB02464, BAB02463). Three proteinases have the motif GxNxFxD (AAM65468, AAB67626, T13023). It also has the motif as DINEFSD (Xaa-Xaa-N-Xaa-F-Xaa-D). The Xaa-XaaN-Xaa-F-Xaa-D format also exists in Nicotiana tabacum L. (78,660), Mesembryanthemum crystallinum L. (AAA74430), and Oryza sativa L. (CAA56844).

MDLLSRFVLL LFSSSLVFAA TASTVSSDES DDLLIRQVVAGADDHDNDDL

LLNAEHHFSSFKKRFGKAYTSCDEHDRRFGVFKANLRRAKRNQILDPSAV

HGVTQFFDLTPAEFRRTYLGLKRLRLPADTHEAPILPTNDLPADFDWRDH

GAVTPVKNQGSCGSCWSFSATGALEGANFLATGKLVSLSEQQLVDCDHVC

DSEDPSSCDSGCNGGLMTSAFEYTLKAGGLEREEDYPYTGTDHSKCKEDK

TKIAVSASNFSVVSLDENQIAANLVTNGPLAIGINAMFMQTYIGGVSCPY ICSKRLLDHGVLLVGYGSAG

FAPIRFKEKPYWIIKNSWGESWGEKGYYKI CRGRNICGMDSMVSAVAAAVPTVN

Fig. 1. Primary structure of deduced cysteine proteinase peptide (accession DQ403257) in Pachysandra terminalis. The polypeptide has a predicted length of 374 amino acids. The signal sequence (1-19) is marked in bold. The Peptidase_C1 domain is italicized (141-367). Protein translation was performed using ExPaSy translation tool (Swiss Institute of Bioinformatics, 2006). The conserved domains were predicted using MotifScan (Falquet et al., 2002). Signal peptide was predicted with the eukaryotic linear motif resources for functional sites in proteins (Puntervoll et al., 2003). 
Table 1 . The conserved motif within the pro region of cysteine proteases of different plant species.

\begin{tabular}{|c|c|c|c|}
\hline Plant species & Gene accession & Propeptide motif & Gene expression \\
\hline Arabidopsis thaliana & AAM96982 & GVTQFSD $^{z}$ & N/A \\
\hline A. thaliana & AAD23687 & GVTQFSD & $\mathrm{N} / \mathrm{A}$ \\
\hline A. thaliana & B84601 & GVTQFSD $^{z}$ & Wilt inducible \\
\hline Phaseolus vulgaris & CAB 17077 & GVTQFSD $^{z}$ & $\mathrm{~N} / \mathrm{A}$ \\
\hline Ipomoea batatas & AAK27969 & GVTQFSD $^{z}$ & $\mathrm{~N} / \mathrm{A}$ \\
\hline Vigna mungo & BAA92495 & GVTKFSD $^{z}$ & Seed germination \\
\hline Pisum sativum & P25804 & GITKFSD $^{z}$ & Turgor-responsive \\
\hline Lycopersicon esculentum & CAA78403 & GITQFSD $^{z}$ & N/A \\
\hline Pachysandra terminalis & DQ403257 & GVTQFFD $^{z}$ & Chilling-inducible \\
\hline Brassica napus & ABA71355 & GVNQFTD $^{z}$ & $\mathrm{~N} / \mathrm{A}$ \\
\hline Solanum tuberosum & CAB53515 & GLTKFAD $^{z}$ & Disease resistance \\
\hline A. thaliana & $\mathrm{T} 13022$ & GLTGFAD $^{\mathrm{z}}$ & Drought-inducible \\
\hline A. thaliana & ВАB 02463 & GLTRFAD $^{z}$ & Unknown \\
\hline L. esculentum & CAA88629 & GINEFTD $^{y}$ & Leaf senescence-inducible \\
\hline L. esculentum & AAM19209 & GMNEFAD $^{\mathrm{y}}$ & Disease resistance \\
\hline Nicotiana tabacum & BAA96501 & GVNEFTD $^{y}$ & Circadian and senescence-enhanced \\
\hline A. thaliana & AAB67626 & GVNEFAD $^{y}$ & $\mathrm{~N} / \mathrm{A}$ \\
\hline P. sativum & CAA92583 & GVNHFAD $^{\mathrm{y}}$ & Seed germination \\
\hline P. vulgaris & CAB17074 & GLNKFAD & Seed germination \\
\hline N. tabacum & CAB16317 & GLNQFAD $^{\mathrm{y}}$ & Seed germination \\
\hline Z. mays & CAA68192 & GINRFAD $^{y}$ & Senescence-enhanced \\
\hline Z. mays & BAA08245 & GINRFAD & Seeds ripe and germination \\
\hline I. batatas & AAK27968 & GINAFAD & Senescence \\
\hline
\end{tabular}

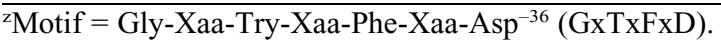

${ }^{y}$ Motif $=$ Gly-Xaa-Asn-Xaa-Phe-Xaa-Asp ${ }^{-36}$ (GxNxFxD).

${ }^{\mathrm{x}}$ Motif $=$ Xaa-Xaa-Asn-Xaa-Phe-Xaa-Asp ${ }^{-36}(\mathrm{XxTxFxD})$.

$\mathrm{N} / \mathrm{A}=$ Not available.

EFFECT OF COLD AND HEAT STRESSES ON GENE EXPRESSION OF THE PUTATIVE CYSTEINE PROTEINASE GENE FROM $P$. TERMINALIS. When the real-time PCR products were separated on $2 \%$ agarose gels, one specific band in all the temperature treatments was observed for the cysteine protease (110 bp) and18S rRNA (100 bp) (Fig. 2). These results validated the primer specificity and efficiency of the real-time PCR.

qRT-PCR measures relative abundance of gene transcripts in different tissues. Results from the current study shows that transcript accumulation of the proteinase gene is affected by darkness, cold, and heat stresses. When plants were incubated at $25{ }^{\circ} \mathrm{C}$, 2-h darkness induced a decrease of gene transcripts present in the leaf tissues. The expression level is lower than control $(0 \mathrm{~h})$ (Table 2). Extending the darkness to $1 \mathrm{~d}, 2 \mathrm{~d}$, and $3 \mathrm{~d}$ induced a continuous elevation of gene transcript accumulation by 2.2-, 3.9-, and 4.3-fold, respectively. The level of the gene transcripts started to decrease at $6 \mathrm{~d}$ and $7 \mathrm{~d}$ and the value became approximately twofold compared with control. The interaction of temperature stresses and darkness caused temporal changes in the induction of the proteinase gene. Combination of short-term $(2 \mathrm{~h})$ cold $\left(5^{\circ} \mathrm{C}\right)$ and darkness $(2 \mathrm{~h})$ induced a 1.83-fold increase. Further exposure to chilling stress delayed the induction of the proteinase gene but increased the multitude. The expression level showed no obvious changes until $3 \mathrm{~d}$, but fold changes increased from fourfold to sevenfold. The most obvious is the 7-d treatment; the cold treatment induced an 8.85 -fold increase compared with 2.56 -fold at $25^{\circ} \mathrm{C}$. The heat stress functions in a similar pattern. The gene induction delayed until $3 \mathrm{~d}$ of treatment, but the intensity was a 9.8 -fold increase.

\section{Discussion}

The pro peptide regions serve a variety of functions in vivo and in vitro. It is required for the proper folding of the newly synthesized enzyme, the inactivation of the proteinase domain, and stabilization of the enzyme against denaturing at neutral 


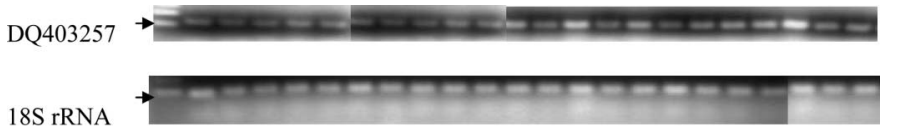

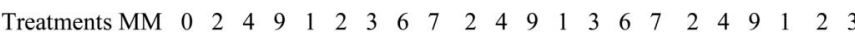
h h h h d d d d d h h h d d d d h h h d d d $25{ }^{\circ} \mathrm{C}-\ldots-\ldots{ }^{\circ} \mathrm{C}-\ldots-38{ }^{\circ} \mathrm{C}-\ldots$

Fig. 2. Agarose gel validation of real-time polymerase chain reactions for a putative proteinase gene and 18S rRNA from leaves of Pachysandra terminalis. The DQ403257 is the cloned putative proteinase gene and 18S rRNA (ribosomal RNA) is the housekeeping gene; $2.5 \%$ agarose gel was used. One specific band was amplified in the real-time polymerase chain reaction from leaves under all the different temperature treatments. Arrows points to 100 base pairs; $\mathrm{MM}=$ DNA molecular marker; $\mathrm{h}=$ incubation hours; $\mathrm{d}=$ incubation days. Numerals indicate the number of hours or days under treatment. Temperatures are indicated under each treatment period.

to alkaline pH conditions (Vernet et al., 1995a). Amino acid residues within the pro region mediate their membrane association and play a role in the transport of the proenzyme to lysosomes. The variation in the conserved motif of plant proteinases is much bigger than in other eukaryotes species. This phenomenon could be related to species and the range of environment in which plants have evolved. However, no relationship can be identified between the variation of the conserved motif and the possible function of the proteinases as indicated by their involvement in different physiological processes (Table 1). This may be the result of limited availability of information on the specific function of different proteinases and from different plant species.

The temperature treatments were performed under continuous darkness, which is different from the diurnal photoperiod that plants normally experience. Results from the current study indicate that the proteinase gene transcription can be suppressed within $2 \mathrm{~h}$ by change of light conditions, or the dark-shock induces degradation of the gene transcripts. Both processes can lower accumulation of gene transcripts in the leaf tissues. The plants will get adjusted to the darkness and maintain the proteinase gene expression similar to control $(0 \mathrm{~h})$ in the next $9 \mathrm{~h}$. However, a longer period $(>1 \mathrm{~d})$ of darkness can induce a light constraint and thus expression of the stressrelated proteinase gene. Changes in gene expression in response to light changes have been documented in other plant species (Wierstra and Kloppstech, 2000).

$P$. terminalis is a cold-hardy herbaceous perennial plant species. The plants can survive -6.6 to $-1.1{ }^{\circ} \mathrm{C}$ (USDA zones $6-9)$. In this study, we noticed that the leaves appear normal within $2 \mathrm{~d}$ when incubated at $38{ }^{\circ} \mathrm{C}$ in total darkness. These observations suggest that the plant species is highly tolerant to both high and low temperature extremes. The qRT-PCR assay shows that proteinase gene transcription remains stable for a minimum of $2 \mathrm{~d}$ under chilling and heat stresses, suggesting that the plants are maintaining a stable state of metabolism during this time period. However, a few leaves started to wilt and dehydrate after $3 \mathrm{~d}$ at $38^{\circ} \mathrm{C}$. Chlorotic spots appeared on some of the young leaves incubated for $6 \mathrm{~d}$ at 5 and $25^{\circ} \mathrm{C}$. Under both conditions, the plants are undergoing a degenerative process. Although the leaf samples were collected from normal-looking plants, they may be experiencing or adjusting to the corresponding changes. That can be the reason why the proteinase gene is highly enhanced at this stage.
Table 2. Fold changes of the steady-state transcript levels for the putative proteinase gene (DQ403257) in Pachysandra terminalis under darkness, cold, and heat stresses. ${ }^{\mathrm{z}}$

\begin{tabular}{lccc}
\hline $\begin{array}{l}\text { Time } \\
\text { period }\end{array}$ & $25^{\circ} \mathrm{C}+$ dark & $5{ }^{\circ} \mathrm{C}+$ dark & $38^{\circ} \mathrm{C}+$ dark \\
\hline $0 \mathrm{~h}$ & $1.00^{\mathrm{x}}(0.91-1.10)^{\mathrm{w}}$ & $1.00(0.91-1.10)$ & $1.00(0.91-1.10)$ \\
$2 \mathrm{~h}$ & $0.66(0.56-0.79)$ & $1.83(1.62-2.06)$ & $1.06(0.61-1.82)$ \\
$4 \mathrm{~h}$ & $1.23(1.04-1.45)$ & $1.16(0.77-1.74$ & $1.10(0.65-1.85)$ \\
$9 \mathrm{~h}$ & $0.91(0.59-1.40)$ & $0.97(0.73-1.28)$ & $0.72(0.43-1.21)$ \\
$1 \mathrm{~d}$ & $2.22(1.71-2.89)$ & $1.20(0.81-1.78)$ & $1.30(0.80-2.12)$ \\
$2 \mathrm{~d}$ & $3.91(2.29-6.67)$ & $-^{\mathrm{v}}$ & $1.55(0.88-2.75)$ \\
$3 \mathrm{~d}$ & $4.34(3.04-6.19)$ & $7.05(5.09-9.75)$ & $9.82(8.57-11.25)$ \\
$6 \mathrm{~d}$ & $2.36(1.66-3.37)$ & $3.00(2.41-3.75)$ & - \\
$7 \mathrm{~d}$ & $2.56(1.81-3.61)$ & $8.85(5.82-13.45)$ & - \\
\hline
\end{tabular}

${ }^{\mathrm{z}}$ All the values are compared with $0 \mathrm{~h}$ in the same column.

${ }^{y}$ Number of hours (h) or days (d) under treatments.

${ }^{x}$ Fold changes of gene transcripts relative to $0 \mathrm{~h}$ and is calculated as $2-\Delta \mathrm{C}_{\mathrm{T}}$ in which $\Delta \mathrm{C}_{\mathrm{T}}$ is the (proteinase $\mathrm{C}_{\mathrm{T}}-18 \mathrm{~S}$ rRNAC $\left.{ }_{\mathrm{T}}\right)_{\mathrm{N}}-$ (proteinase $\mathrm{C}_{\mathrm{T}}-18 \mathrm{~S}$ rRNAC $\left.\mathrm{T}_{0}\right)_{0} ; \mathrm{N}$ refers to the treatment of $\mathrm{N}(\mathrm{h} / \mathrm{d}) ; 0$ refers to $0 \mathrm{~h}$. ${ }^{w}$ Range of the gene expression relative the control calculated using $\Delta \mathrm{C}_{\mathrm{T}+\mathrm{s}}$ and $\Delta \mathrm{C}_{\mathrm{T}-\mathrm{s}}$, in which $\mathrm{s}=$ the standard deviation of the $\Delta \mathrm{C}_{\mathrm{T}}$ value. The calculation procedure was following the relative quantification using the comparative $\mathrm{C}_{\mathrm{T}}$ method (ABI Prism 7700 Sequence Detection System, User Bulletin \#2; Applied Biosystems, Foster City, Calif.).

${ }^{\mathrm{v}}$ Quantitative reverse transcriptase-polymerase chain reaction not performed.

In plants and other organisms, proteinase activity can be regulated at different levels: by transcription/translation, by posttranslational processing, and by specific proteinase inhibitor proteins (Bode and Huber, 1992). Cold and heat stresses can induce breakdown of cellular structure (Ilker et al., 1979) and leakage of solutes and electrolytes (Lieberman et al., 1958) that could lead to polypeptide denaturation. The proteinases might function by degrading polypeptides damaged or denatured by exposure to temperature stresses. In tomato (L. esculentum) unripe fruit under $4{ }^{\circ} \mathrm{C}$ cold treatment, induction of a papain-like thiol proteinase gene expression was detected after $8 \mathrm{~h}$ and kept on increasing after 16 and $48 \mathrm{~h}$ incubation (Schaffer and Fischer, 1988, 1990). The current study showed that the cold regulation of the putative cysteine proteinase gene was time-dependent. It was enhanced after $2 \mathrm{~h}$ followed by a phase of recovering back to the control (before cold treatment) level within $1 \mathrm{~d}$. Compared with the coldsensitive tomato, Pachysdandra terminalis has much higher tolerance to low temperature. Based on the cold tolerance characteristics and gene expression pattern, it is postulated that one of the mechanisms for cold tolerance is that the tolerant plants will respond very fast to the environmental stress by expression of stress-related genes such as the proteinase to eliminate the denatured proteins or to activate other stress-related enzymes. After the initial phase, the plants will return to a normal metabolism state and thus the proteinase gene expression will start to decrease. However, a long period of chilling stresses $(>3 \mathrm{~d})$ may induce changes in cellular metabolism system, in which the enhanced expression of the proteinase is one of the components.

\section{Literature Cited}

Avrova, A.O., H.E. Stewart, W.D. De Jong, J. Heilbronn, G.D. Lyon, and P.R. Birch. 1999. A cysteine protease gene is expressed early in resistant potato interactions with Phytophthora infestans. Mol. Plant Microbe Interact. 12:1114-1119. 
Becker, C., J. Fischer, V.H. Nong, and K. Munitz. 1994. PCR cloning and expression analysis of cDNAs encoding cysteine proteinases from germinating seeds of Vicia sativa L. Plant Mol. Biol. 26:1207-1212.

Bode, W. and R. Huber. 1992. Natural protein proteinase inhibitors and their interaction with proteinases. European J. Biochem. 204:433451.

Charrier, B., A. Champion, Y. Henry, and M. Kreis. 2002. Expression profiling of the whole arabidopsis shaggy-like kinase multigene family by real-time reverse transcriptase-polymerase chain reaction. Plant Physiol. 130:577-590.

Chollet, R. and L.L. Anderson. 1977. Conformational changes associated with the reversible cold activation of rubisco-1, 5-bisphosphate carboxylase-oxygenase. Biochim. Biophys. Acta 482:228-240.

Domoto, C., H. Watanabe, M. Abe, K. Abe, and S. Arai. 1995. Isolation and characterization of two distinct cDNA clones encoding corn seed cysteine proteinases. Biochim. Biophys. Acta 1263:241-244.

Drake, R., I. Farrell, W. Cooper, W. Schuch, and D. Grierson. 1996. Isolation and analysis of cDNAs encoding tomato cysteine proteases expressed during leaf senescence. Plant Mol. Biol. 30:755-767.

Falquet, L., M. Pagni, P. Bucher, N. Hulo, C.J. Sigrist, K. Hofmann, and A. Bairoch. 2002. The PROSITE database, its status in 2002. Nucleic Acids Res. 30:235-238.

Griffiths, C.M., S.E. Hosken, D. Oliver, J. Chojecki, and H. Thomas. 1997. Sequencing, expression pattern and RFLP mapping of a senescence-enhanced cDNA from Zea mays with high homology to oryzain gamma and aleurain. Plant Mol. Biol. 34:815-821.

Grzywnowicz, K., M. Brzyska, J. Lobarzewski, and H. Greppin. 1992. Changes in activity of soluble and immobilized cabbage peroxidase after treatment with seven different proteases. J. Mol. Catal. 77:365-376.

Grzywnowicz, K., H. Greppin, M. Brzyska, and J. Lobarzewski. 1993. Changes in activity of soluble and immobilized peroxidases after treatment by various proteases and some metal ions. J. Mol. Catal. 80:117-125.

Guerrero, F.D., J.T. Jones, and J.E. Mullet. 1990. Turgor-responsive gene transcription and RNA levels increase rapidly when pea shoots are wilted. Sequence and expression of three inducible genes. Plant Mol. Biol. 15:11-26.

Harrak, H., S. Azelmat, E.N. Baker, and Z. Tabaeizadeh. 2001. Isolation and characterization of a gene encoding a drought-induced cysteine protease in tomato (Lycopersicon esculentum). Genome 44:368-374.

Ilker, R., R.W. Breidenbach, and J.M. Lyons. 1979. Sequence of ultrastructural changes in tomato cotyledons during short period of chilling, p. 97-113. In: J.M. Lyons, D. Graham, and J.K. Raison (eds.). Low temperature stress in crop plants. Academic Press, N.Y. Invitrogen. 2006. Custom primers-OligoPerfect Designer. 15 May 2006. $<$ http://www.invitrogen.com/content.cfm?pageid=9716 $>$.

Jones, C.G., G.A. Tucker, and G.W. Lycett. 1996. Pattern of expression and characteristics of a cysteine proteinase cDNA from germinating seeds of pea (Pisum sativum L.). Biochim. Biophys. Acta 1296:13-15.

Jones, M.L., G.S. Chaffin, J.R. Eason, and D.G. Clark. 2005. Ethylenesensitivity regulates proteolytic activity and cysteine protease gene expression in Petunia corollas. J. Expt. Bot. 56:2733-2744.

Kassell, B. and J. Kay. 1973. Zymogens of proteolytic enzymes. Science 180:1022-1027.

Koizumi, M., K. Yamaguchi-Shinozaki, H. Tsuji, and K. Shinozaki. 1993. Structure and expression of two genes that encode distinct drought-inducible cysteine proteinases in Arabidopsis thaliana. Gene 129:175-182.

Lammers, P.J., J. Jun, J. Abubaker, R. Arreola, A. Gopalan, B. Bago, C. Hernandez-Sebastia, J.W. Allen, D.D. Douds, P.E. Pfeffer, and Y. Shachar-Hill. 2001. The glyoxylate cycle in an arbuscular mycorrhizal fungus. Carbon flux and gene expression. Plant Physiol. 127:1287-1298.

Lieberman, M., C.C. Croft, W.V. Audia, and M.S. Wilcox. 1958. Biochemical studies of chilling injury in sweet potatoes. Plant Physiol. 33:307-311.
Neurath, H. 1984. Evolution of proteolytic enzymes. Science 224:350-357. Okamoto, T., K. Toyooka, and T. Minamikawa. 2001. Identification of a membrane-associated cysteine protease with possible dual roles in the endoplasmic reticulum and protein storage vacuole. J. Biol. Chem. 276:742-751.

Provart, N.J., P. Gil, W.Q. Chen, B. Han, H.-S. Chang, X. Wang, and T. Zhu. 2003. Gene expression phenotypes of phenotypes of arabidopsis associated with sensitivity to low temperature. Plant Physiol. 132:893-906.

Puntervoll, P., R. Linding, C. Gemünd, S. Chabanis-Davidson, M. Mattingsdal, S. Cameron, D.M.A. Martin, G. Ausiello, B. Brannetti, A. Costantini, F. Ferrè, V. Maselli, A. Via, G. Cesareni, F. Diella, G. Superti-Furga, L. Wyrwicz, C. Ramu, C. McGuigan, R. Gudavalli, I. Letunic, P. Bork, L. Rychlewski, B. Küster, M. Helmer-Citterich, W. Hunter, R. Aasland, and T.J. Gibson. 2003. ELM server: A new resource for investigating short functional sites in modular eukaryotic proteins. Nucleic Acids Res. 31:3625-3630.

Rawlings, N.D. and A.J. Barrett. 1994. Families of cysteine peptidases. Methods Enzymol. 244:461-486.

Schaffer, M.A. and R.L. Fischer. 1988. Analysis of mRNAs that accumulate in response to low temperature identifies a thiol protease gene in tomato. Plant Physiol. 87:431-436.

Schaffer, M.A. and R.L. Fischer. 1990. Transcriptional activation by heat and cold of a thiol protease gene in tomato. Plant Physiol. 93:1486-1491.

Shintani, A., D. Yamauchi, and T. Minamikawa. 1995. Nucleotide sequence of cDNA for a putative cysteine protease from rice seeds. Plant Physiol. 107:1025.

Solomon, M., B. Belenghi, M. Delledonne, E. Menachem, and A. Levine. 1999. The involvement of cysteine proteases and protease inhibitor genes in the regulation of programmed cell death in plants. Plant Cell 11:431-443.

Swiss Institute of Bioinformatics. 2006. Translate tool. 30 May 2006. $<\mathrm{http}$ :/www.expasy.org/tools/dna.html $>$.

Tsuji, A., M. Tsuji, H. Takami, S. Nakamura, and Y. Matsuda. 2004. Molecular cloning and expression analysis of novel wheat cysteine protease. Biochim. Biophys. Acta 1670:84-89.

Ueda, T., S. Seo, Y. Ohashi, and J. Hashimoto. 2000. Circadian and senescence-enhanced expression of a tobacco cysteine protease gene. Plant Mol. Biol. 44:649-657.

van der Hoorn, R.A.L., M.L. Leeuwenburgh, M. Bogyo, M.H.A.J. Joosten, and S.C. Peck. 2004. Activity profiling of papain-like cysteine proteases in plants. Plant Physiol. 135:1170-1178.

Vernet, T., P.J. Berti, C. de Montigny, R. Musil, D.C. Tessier, R. Ménard, M.-C. Magny, A.C. Storer, and D.Y. Thomas. 1995a. Processing of the papain precursor. The ionization state of a conserved amino acid motif within the pro region participates in the regulation of intramolecular processing. J. Biol. Chem. 270:10838-10846.

Vernet, T., D.C. Tessier, J. Chatellier, C. Plouffe, T.S. Lee, A.Y. Thomas, A.C. Storer, and R. Menard. 1995b. Structural and functional roles of asparagines 175 in the cysteine protease papain. J. Biol. Chem. 270:16645-16652.

Wierstra, I. and K. Kloppstech. 2000. Differential effects of methyl jasmonate on the expression of the early light-inducible proteins and other light-regulated genes in barley. Plant Physiol. 124:833844.

Williams, J., M. Bulman, A. Huttly, A. Phillips, and S. Neill. 1994. Characterization of a cDNA from Arabidopsis thaliana encoding a potential thiol protease whose expression is induced independently by wilting and abscisic acid. Plant Mol. Biol. 25:259-270.

Zhou, S.P., F.-C. Chen, S. Nahashon, and T.T. Chen. 2006. Cloning and characterization of glycolate oxidase and NADH-dependent hydropyruvate reductase genes in Pachysandra terminals Sieb. \& Zucc. HortScience 41:1226-1230.

Zhou, S.P., R. Sauve, and A. Abudullah. 2005. Identification of genes regulated by low temperature in Pachysandra terminalis Sieb. et Zuuc. using cDNA differential display. HortScience 40:1995-1997. 